\title{
Pharmacological Assessment, Green synthesis and Characterization of Silver Nanoparticles of Sonneratia apetala Buch.-Ham. Leaves
}

\author{
Peddinti Nagababu, Vanga Umamaheswara Rao* \\ Department of Botany and Microbiology, AcharyaNagarjuna University, Nagarjuna Nagar - 522 510, Guntur, Andhra Pradesh, India.
}

\begin{tabular}{|c|c|}
\hline ARTICLE INFO & ABSTRACT \\
\hline $\begin{array}{l}\text { Article history: } \\
\text { Received on: } 28 / 01 / 2017 \\
\text { Accepted on: } 30 / 04 / 2017 \\
\text { Available online: } 30 / 08 / 2017\end{array}$ & $\begin{array}{l}\text { The present investigation evaluates phytochemical screening, antibacterial, antioxidant activities and green } \\
\text { synthesis, characterization of silver nanoparticles and its antibacterial activity. Three dissimilar solvents viz., } \\
\text { hexane, ethyl acetate and methanol were used to prepare crude extracts of Sonneratia apetala leaves to study the } \\
\text { phytochemicals, antibacterial and antioxidant activities. Green synthesis, characterization of silver nanoparticles }\end{array}$ \\
\hline $\begin{array}{l}\text { Key words: } \\
\text { Sonneratia apetala; } \\
\text { Phytochemical screening; } \\
\text { Antioxidant activity; Silver } \\
\text { nanoparticles; FTIR } \\
\text { spectroscopy; Antibacterial } \\
\text { activity. }\end{array}$ & $\begin{array}{l}\text { examined by means of DPPH free radical scavenging method. AgNPs were synthesized by using } 1 \mathrm{mM} \text { AgNO } \\
\text { solution mixed with leaf aqueous extract of } S \text {. apetala. The characterization of the prepared AgNPs was done by } \\
\text { UV-Vis spectrometry, FTIR spectroscopy and Scanning electron microscopy. Antibacterial activity was studied } \\
\text { by agar well diffusion method. The phytochemical screening results unveiled the bearing of different } \\
\text { phytochemicals viz., flavonoids, alkaloids, saponins, carbohydrates, terpenoids, steroids, tannins and free } \\
\text { anthraquinones particularly with relatively high abundance in methanol extract. Likewise methanol extract too } \\
\text { exhibited effective free radical scavenging and antibacterial activities. The characterization results of the } \\
\text { prepared AgNPs displayed that the silver nanoparticles are formed and stabilized by plant phyto-constituents } \\
\text { and also exhibited virtuous antibacterial property with great antagonism towards Proteus mirabilis with } 27.3 \\
\text { mm diameter zone of inhibition. Green synthesis process is a pivotal area in nanotechnology and usage of } \\
\text { natural resources is the best choice for the making of NPs as a sustainable, eco-friendly, inexpensive and free of } \\
\text { chemical contaminant method. These AgNPs have several potential biological and medical applications. }\end{array}$ \\
\hline
\end{tabular}

\section{INTRODUCTION}

There is an imperative need to explore new warfare schemes to combat against multi drug resistant bacteria and also to subdue the problems of chemical drug consumption in order to control the microbial infections. These drugs from plants are less harmful, side effects are minimal and also cost effective (Harishchandra et al., 2012). Mangroves are common salt permissive plants with an origin of tropical and subtropical intertidal regions of the world. With reference to the much potency of mangroves, research is advancing on mangrove plants especially to study their chemical constituents. The undisclosed factors influencing the orchestrated research on mangrove plants

\footnotetext{
* Corresponding Author

E-mail: umrvanga@yahoo.co.in
}

ensues from the fact that mangroves belong to a group of tropical forests which can be easily generated. As stated, they can survive where other plants would not have survived. This is because they can withstand seemingly harsh environments including high moisture concentrations, low and high tides as well as in the presence of large population of insects and other living microorganisms (Sachin et al., 2014). Mangrove plants possess some compounds with special potential antifungal, antibacterial, and antiviral properties which can be isolated from mangrove plants, and they contain large percentage of disease preventing phytochemicals as they have been widely reported to be viable sources for flavonoids, saponins and alkaloids (Nebula et al., 2013). Antioxidant compounds in foods play a critical role as health protecting factors. Scientific evidences indicated that antioxidants decrease the risk of chronic diseases such as cancer and cardiovascular and gastrointestinal diseases (Mardani et al., 2016). 
Mangrove plants are rich in natural antioxidants and also contain bioactive compounds which are active against many pathogenic bacteria. Production of NPs is a sort of bottom up approach, with reduction/oxidation as the key reaction which seems as a superior substitute to battle against the multi-drug resistance bacteria. The usage of NPs is attaining impulse in the contemporary period due to their distinct mechanical, optical and chemical properties (Siva kumar et al., 2011). Biotic approaches can be employed to synthesize AgNPs without use of toxic, harsh and costly chemical substances. Safety, better accessibility, nontoxicity in most cases, having broad variety of metabolites that can involve in silver ions reduction and faster rate of nanoparticle formation than in microbes are the major advantages of utilizing plants for the purpose of AgNPs synthesis. The key mechanism concerned in the method is plant phytochemical aided reduction. Quinones, flavones and organic acids are the utmost chief watersoluble phytochemicals that are accountable for the quick reduction of the ions. Hence, there is a continuous and urgent need to discover new antimicrobial compounds with diverse chemical structures and novel mechanism of action because there has been an alarming increases in the incidence of new and re-emerging infectious diseases (Anand et al., 2011). The present study aimed to assess the qualitative nature of the phytochemical constituents and to evaluate the antibacterial and antioxidant activities of $S$. apetala leaf extracts. Green synthesis of plant leaf mediated silver nanoparticles, its characterization and antibacterial activity were also attempted as there is no earlier report on the green synthesis of $S$. apetala leaf AgNPs.

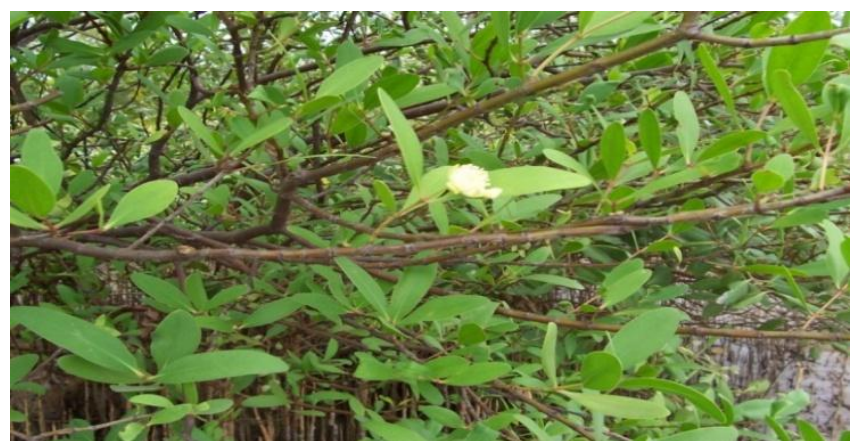

Fig. 1: Sonneratia apetala plant.

\section{MATERIALS AND METHODS}

Sonneratia apetala (Fig-1), member of Lythraceae family is a fast-growing evergreen mangrove tree with a columnar crown. It rises up to $20 \mathrm{~m}$ tall, but more commonly to between 12 and $15 \mathrm{~m}$ height. The tree produces pneumatophores up to $1.5 \mathrm{~m}$ tall. Sonneratia is generally called as mangrove apple in English. This plant is normally introduced as a fast-growing tree for reforestation of mangrove communities.

\section{Phytochemical screening}

\section{Preparation of the plant solvent extracts}

Leaves of $S$. apetala plant were collected from Coringa Mangrove Forest near Kakinada, Andhra Pradesh, shade dried and powdered using mechanical grinder. Crude extracts were made using different solvents viz., hexane, ethyl acetate and methanol by Soxhlet extractor. The resulted solvent extracts were evaporated using Roto evaporator. The dried and/or semi dried extract material was used for the phytochemical screening. Standard phytochemical methods were employed for the qualitative analysis of different phytochemicals viz., Flavonoids (Ferric chloride test, Shinoda's test, Sodium hydroxide test, Lead acetate test), Alkaloids, Saponins, Terpenoids, Steroids (Salkowskii test, KellerKilliani test, Liebermann-Burchard test), Carbohydrates (Molisch's test, Fehling's tests for free reducing sugars and combined reducing sugars, Barfoed's test for monosaccharides), Tannins (Borntrager's test, Phlonatanins test) and soluble starch (Harborne, 1973)

\section{Green synthesis and Characterization of silver nanoparticles}

Fifteen grams of powdered leaf material of S. apetala was added to $100 \mathrm{ml}$ of double distilled water and boiled for 15 minutes at $60^{\circ} \mathrm{C}$. Later allowed the solution to cool to room temperature, the extract was filtered using Whatman No.1 filter paper and stored at $4{ }^{\circ} \mathrm{C}$ for further analysis. Then, the filtrate (20 $\mathrm{ml}$ ) was added with $80 \mathrm{ml}$ of aqueous $1 \mathrm{mM}$ silver nitrate $\left(\mathrm{AgNO}_{3}\right)$ solution and heated at $60^{\circ} \mathrm{C}$ temperature and observed for the development of brown-yellow solution that indicates the formation of AgNPs. For further confirmation of AgNPs formation, the brown-yellow solution was subjected to Ultraviolet-Visible Spectrometry.

The so formed brown-yellow solution was centrifuged at 20, $000 \mathrm{rpm}$ for 30 minutes and the obtained pellet was washed thrice with double distilled water and then dried at $60^{\circ} \mathrm{C}$. After drying, powdered form of NPs was preserved for further characterization. The infrared spectra of absorption and emission of the formed AgNPs was acquired by FTIR. The morphology of the prepared AgNPs was examined with SEM.

\section{Antibacterial activity of leaf extracts and AgNPs Test organisms used}

The antibacterial activity of the crude extracts was tested against both Gram +ve and Gram -ve bacteria. Nine Gram +ve bacteria including Staphylococcus aureus MTCC 737, Micrococcus luteus MTCC 106, Enterococcus faecalis MTCC 439, Bacillus subtilis MTCC 441, Arthrobacter protophormiae MTCC 2682, Bacillus megaterium MTCC 428, Rhodococcus rhodochrous MTCC 265, Lactobacillus acidophilus MTCC 10307 and Streptococcus mutans MTCC 497 and six Gram -ve bacteria including Proteus vulgaris MTCC 426, Alcaligens faecalis MTCC 126, Salmonella enterica MTCC 3858, Enterobacter aerogenes MTCC 10208, Proteus mirabilis MTCC 425 and Pseudomonas aeruginosa MTCC 1688 were used in the study.

\section{Antibacterial activity}

Antibacterial activity was checked by agar well diffusion method (Nagababu and Umamaheswara Rao, 2012). Bacterial suspensions of different test organisms were prepared using $24 \mathrm{hrs}$ 
old bacterial cultures and cultivated $(100 \mu \mathrm{l})$ on agar medium. With a sterile cork borer, $6 \mathrm{~mm}$ diameter wells were made in solidified agar plates. Streptomycin $(10 \mu \mathrm{g} / \mathrm{ml}$ in DMSO) was used as positive control. A minute quantity of sterile agar suspension was placed at the bottom of the well to prevent the leakage and $100 \mu \mathrm{l}$ of the crude elicit sample made by dissolving $100 \mathrm{mg}$ of crude in $1 \mathrm{ml}$ of DMSO was added to each well. DMSO was taken in separate well as the control. Then, plates were incubated at $37^{\circ}$ $\mathrm{C}$ for $24 \mathrm{hrs}$. After incubation, inhibition zone diameter was measured.

For each crude extract sample and bacterial species, triplicates were maintained. Antibacterial activity of synthesized AgNPs was tested against both Gram +ve and Gram -ve bacteria (Nagababu and Umamaheswara Rao, 2016). Into each agar well, $100 \mu \mathrm{l}$ of sample prepared by dispersing $100 \mu \mathrm{g}$ of nanoparticle material in $1 \mathrm{ml}$ of dimethyl sulfoxide (DMSO) was placed. In a separate well, DMSO was placed to maintain the control. After 24 hrs incubation (at $37^{\circ} \mathrm{C}$ ), the diameter of the clear zone was measured. For each sample and bacterial species, triplicates were maintained.

\section{Determination of Minimum Inhibitory Concentration (MIC) and Minimum Bactericidal Concentration (MBC)} MIC and MBC were determined at different concentrations viz., $12.5 \mathrm{mg} / \mathrm{ml}, 25 \mathrm{mg} / \mathrm{ml}, 50 \mathrm{mg} / \mathrm{ml}, 75 \mathrm{mg} / \mathrm{ml}$ and $100 \mathrm{mg} / \mathrm{ml}$ on those bacterial strains which showed sensitivity towards crude extracts of the leaves, by following the broth dilution and plating method (Umamaheswara Rao and Nagababu, 2014). Control tube was maintained for each test concentration. The lowest concentration of the extract that developed no visible bacterial growth in comparison with the control tubes was regarded as MIC. However, MBC was ascertained by sub culturing the test dilution with no growth on to a fresh drug-free solid medium and incubated further for 18-24 hours. The highest dilution that gave no individual bacterial colony on agar medium was confirmed as MBC.

\section{In vitro antioxidant assay [DPPH (2, 2-diphenyl-1-picryl hydrazyl) Free radical scavenging activity]}

The antioxidant activity of different concentrations (100 $\mu \mathrm{g} / \mathrm{ml}, 200 \mu \mathrm{g} / \mathrm{ml}, 300 \mu \mathrm{g} / \mathrm{ml}, 400 \mu \mathrm{g} / \mathrm{ml}$ and $500 \mu \mathrm{g} / \mathrm{ml}$ ) crude extracts was measured by following the established method (Chew et al., 2012). One $\mathrm{ml}$ of each concentration was added with $4 \mathrm{ml}$ of the $0.004 \%(\mathrm{w} / \mathrm{v})$ solution of DPPH prepared in methanol. The reaction mixture was kept for incubation in dark for 30 minutes. Methanol and Ascorbic acid were used as control and positive control, respectively. The absorbance was measured at $517 \mathrm{~nm}$.

The DPPH scavenging activity (\%) was calculated by the following formula

DPPH scavenging activity $(\%)=[(\mathrm{AO}-\mathrm{AS}) / \mathrm{A}] \times 100$

Where, AO - absorbance of the control, AS - absorbance of the plant sample

\section{RESULTS}

\section{Phytochemical screening}

Phytochemical screening of the leaf extracts disclosed that the solvent extracts contain almost all phytochemicals tested including alkaloids, terpenoids, flavonoids, saponins, carbohydrates, steroids, tannins and free anthraquinones (Table-1). Methanol crude extract was positive for all the phytochemicals tested relatively with high abundance.

Table 1: Phytochemical analysis of Sonneratia apetala Leaf extracts of different solvents.

\begin{tabular}{clllc}
\hline S.No. & \multicolumn{1}{c}{ Phytochemicals } & H & E & M \\
\hline 1. & Carbohydrates & -- & + & + \\
2. & Monosaccharides & -- & + & ++ \\
3. & Free reducing sugars & -- & -- & ++ \\
4. & Combined reducing sugars & -- & -- & ++ \\
5. & Tannins & -- & + & ++ \\
6. & Free anthraquinones & -- & + & ++ \\
7. & Steroids & + & ++ & ++ \\
8. & Cardiac glycosides & + & ++ & ++ \\
9. & Terpenoids & + & + & + \\
10. & Saponins & -- & + & ++ \\
11. & Flavonoids & -- & ++ & ++ \\
12. & Soluble starch & -- & ++ & ++ \\
13. & Alkaloids & -- & ++ & ++ \\
\hline
\end{tabular}

H - Hexane; E - Ethyl Acetate; $\mathrm{M}$ - Methanol.

-- Negative; + Positive.

For all phytochemicals tested, ethyl acetate extract was positive except the free reducing sugars and combined reducing sugars. Only cardiac glycosides, steroids and terpenoids were found in hexane extract. The phytochemical results of our present study are in good concurrence with the reports of these earlier studies.

\section{Antibacterial activity of leaf extracts}

The antibacterial activity of different solvent extracts of S. apetala leaves is given in Fig-2. The results showed that the crude extracts of $S$. apetala leaves own the antibacterial activity against both Gram +ve and Gram -ve bacteria. The antibacterial activity of methanol extract was noticed to be comparatively higher than that other solvent extracts.

The greater zone of inhibition was $8.6 \mathrm{~mm}$ and $8.0 \mathrm{~mm}$ against Micrococcus luteus and Arthrobacter protophormiae, respectively. The methanolic extract exhibited activity against almost all the test organisms but not for Salmonella enterica. Hexane extract's antibacterial action was evidenced with Rhodococcus rhodochrous, Micrococcus luteus and Staphylococcus aureus.

Ethyl acetate extract exhibited antibacterial activity against Micrococcus luteus, Streptococcus mutans and Proteus mirabilis. The crude methanol extract demoed more antibacterial activity towards Arthrobacter protophormiae, Staphylococcus aureus and Alcaligens faecalis than that of Streptomycin which is considered as positive control. On the whole, differences in antibacterial activities between the extracts were observed. 


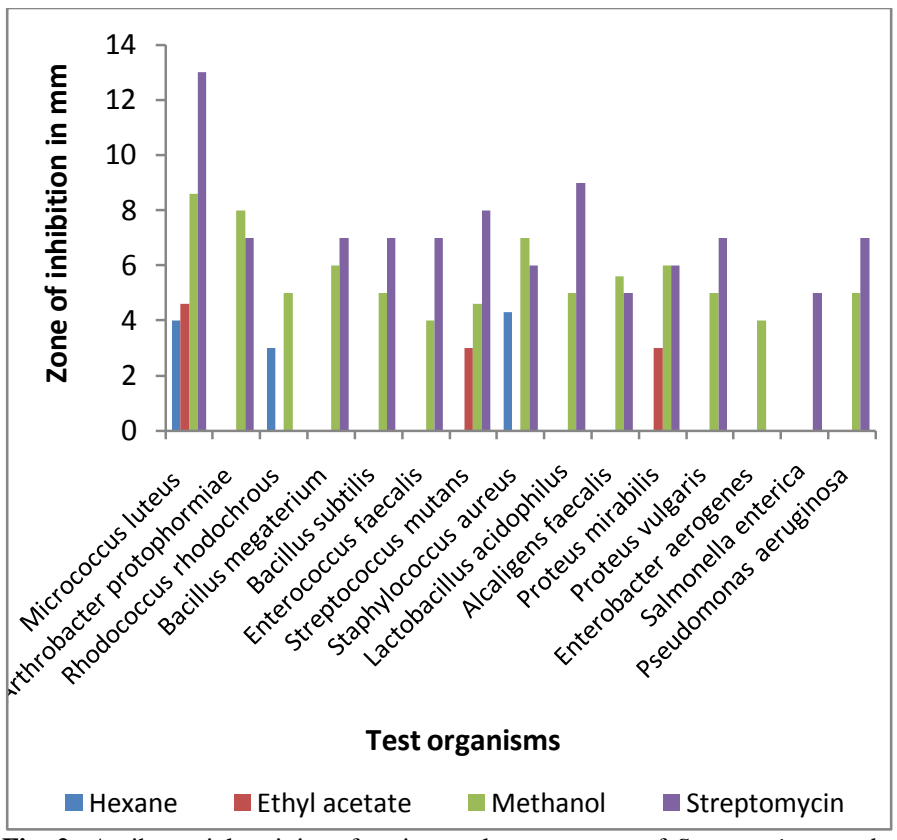

Fig. 2: Antibacterial activity of various solvent extracts of Sonneratia apetala leaves.

\section{Minimum Inhibitory Concentration (MIC) and Minimum Bactericidal Concentration (MBC)}

The MIC and MBC values (Table-2) were recorded for methanol extract against the susceptible bacteria. The MIC value ranged from the lowest of $12.5 \mathrm{mg} / \mathrm{ml}$ against Micrococcus luteus to highest of $75 \mathrm{mg} / \mathrm{ml}$ against Streptococcus mutans, Bacillus subtilis, Lactobacillus acidophilus and Pseudomonas aeruginosa. The range of MBC values found was $25 \mathrm{mg} / \mathrm{ml}$ (Micrococcus luteus) to $100 \mathrm{mg} / \mathrm{ml}$ (Bacillus subtilis, Streptococcus mutans, Lactobacillus acidophilus and Pseudomonas aeruginosa).

Table 2: MIC and MBC (mg/ml) values of Sonneratia apetala leaf methanol extract.

\begin{tabular}{lcc}
\hline \multicolumn{1}{c}{ Test organisms } & \multicolumn{2}{c}{ Methanol } \\
\cline { 2 - 3 } & MIC & MBC \\
\hline Micrococcus luteus MTCC 106 & 12.5 & 25 \\
Arthrobacterprotophormiae MTCC 2682 & 25 & 50 \\
Rhodococcusrhodochrous MTCC 265 & 50 & 75 \\
Bacillus megaterium MTCC 428 & 50 & 75 \\
Bacillus subtilis MTCC 441 & 75 & 100 \\
Streptococcus mutans MTCC 497 & 75 & 100 \\
Staphylococcus aureus MTCC 737 & 50 & 75 \\
Lactobacillus acidophilus MTCC 10307 & 75 & 100 \\
Alcaligensfaecalis MTCC 126 & 50 & 75 \\
Proteus mirabilis MTCC 425 & 25 & 50 \\
Proteus vulgaris MTCC 426 & 50 & 75 \\
Pseudomonas aeruginosa MTCC 1688 & 75 & 100 \\
\hline
\end{tabular}

\section{In vitro antioxidant assay [DPPH (2, 2-diphenyl-1-picryl hydrazyl) Free radical scavenging activity]}

DPPH is a free radical compound usually used to test free radical scavenging ability of different types of samples. The antioxidant activity of various extracts of $S$. apetala leaves (Fig.3) unveiled the free radical scavenging potency of the methanolic extract. At all the concentrations tested, the methanol extract showed greater scavenging activity than the other extracts as well as the positive control i.e., ascorbic acid. The percent DPPH free radical scavenging activity of methanol extract ranged from $65.31 \%(100 \mu \mathrm{g} / \mathrm{ml}$ conc.) to $92.12 \%$ (500 $\mu \mathrm{g} / \mathrm{ml}$ conc.). However, the scavenging activity of all the extracts and positive control increased with the rise in the concentration of the samples.

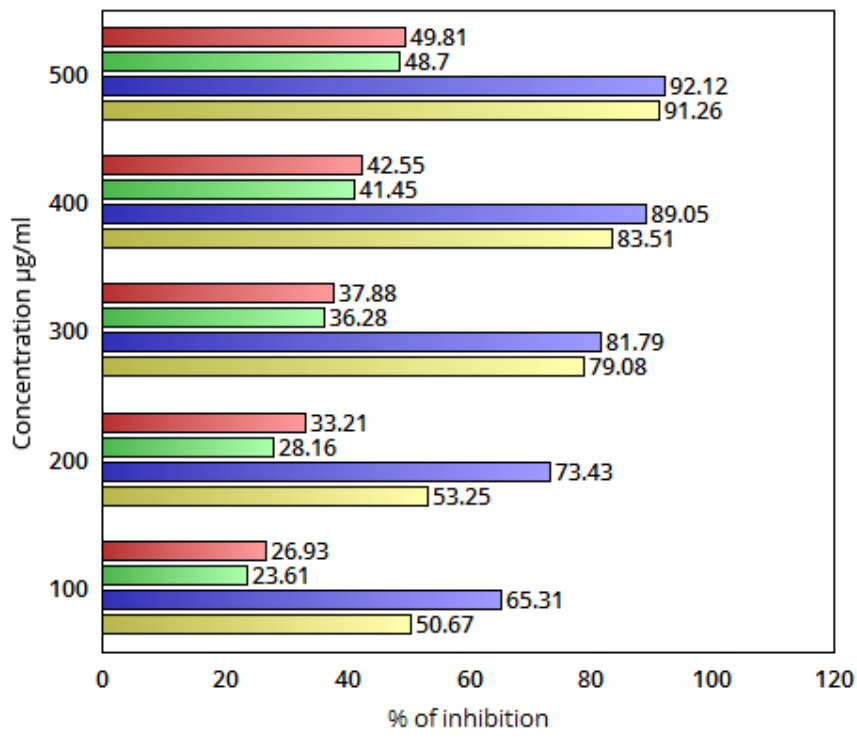

$\square$ Hexane $\quad \square$ Ethyl acetate $\quad \square$ Methanol

$\square$ Ascorbic acid

Fig. 3: DPPH free radical scavenging activity of various solvent extracts of Sonneratia apetala leaves

\section{UV-Visible, FTIR and SEM}

The reduction of AgNPs synthesized with leaf extract of S. apetala was indicated by a color change of brown to dark brown solution as shown in the Fig-4.

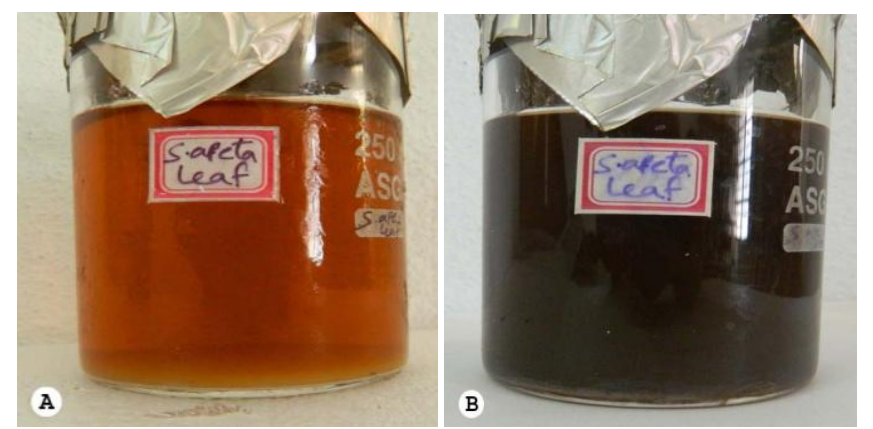

Fig. 4:

A) Plant extract with $\mathrm{AgNO}_{3}$ solution before reaction.

B) Dark brown solution after reaction with $\mathrm{AgNO}_{3}$ solution.

Synthesis of the AgNPs in aqueous solution was checked by recording the absorption spectrum at a wavelength range of 200-700 nm. The UV-Vis absorption spectrum of AgNPs (Fig-5) obtained showed the absorption maxima ranged from 425 to 475 $\mathrm{nm}$ which gives the confirmation for the AgNPs synthesis. The FTIR analysis (Fig-6) of S. apetala leaf AgNps exhibited peaks at $1619 \mathrm{~cm}-1$ and $3417 \mathrm{~cm}-1$ indicating the possible interaction between proteins and silver nanoparticles. The remaining peaks 
found in the spectrum viz., 2926.16, 1383.36, 1095.29 and 595.70 are possibly reflecting the $\mathrm{CH}$ stretching, $-\mathrm{C}=\mathrm{C}$ - stretching, $\mathrm{C}-\mathrm{N}$ stretching vibration of the amine and $\mathrm{CH}$ bending vibration, respectively. AgNPs that gave the spectrum were examined under Scanning Electron Microscope. The SEM image silver nanoparticles (Fig-7) clearly showed the well dispersed particles that are almost spherical.

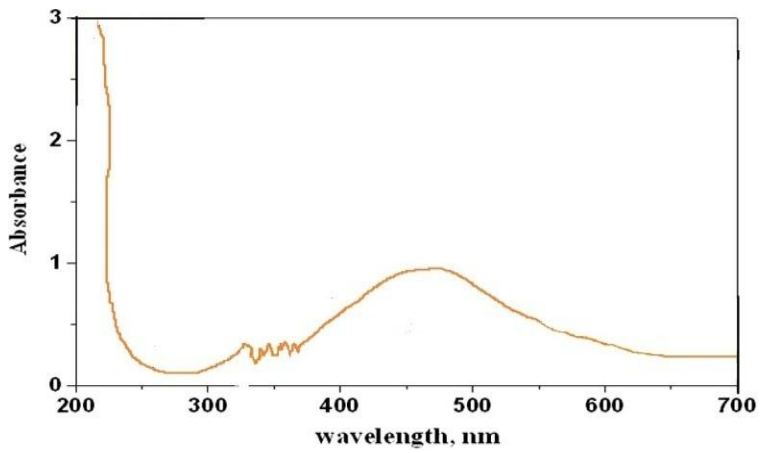

Fig. 5: UV-Vis spectra of Sonneratia apetala leaf extract AgNPs.

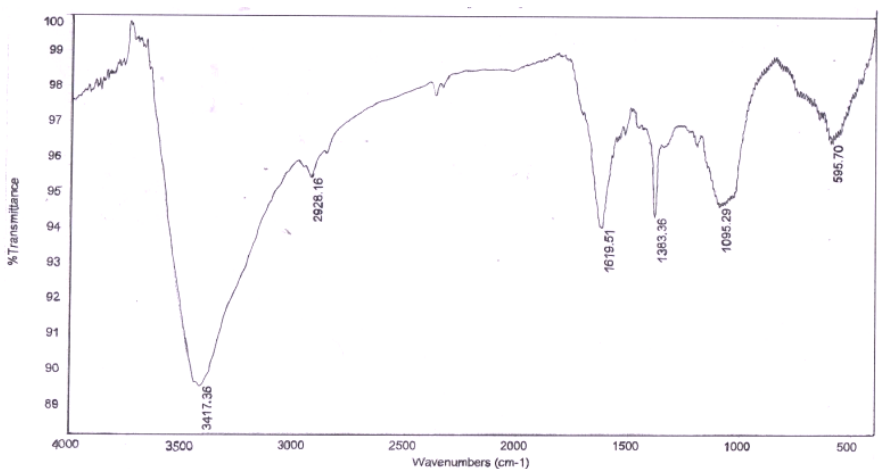

Fig. 6: FT-IR spectrum of AgNPs synthesized by reacting $\mathrm{AgNO}_{3}$ with Sonneratia apetala leaf extract.

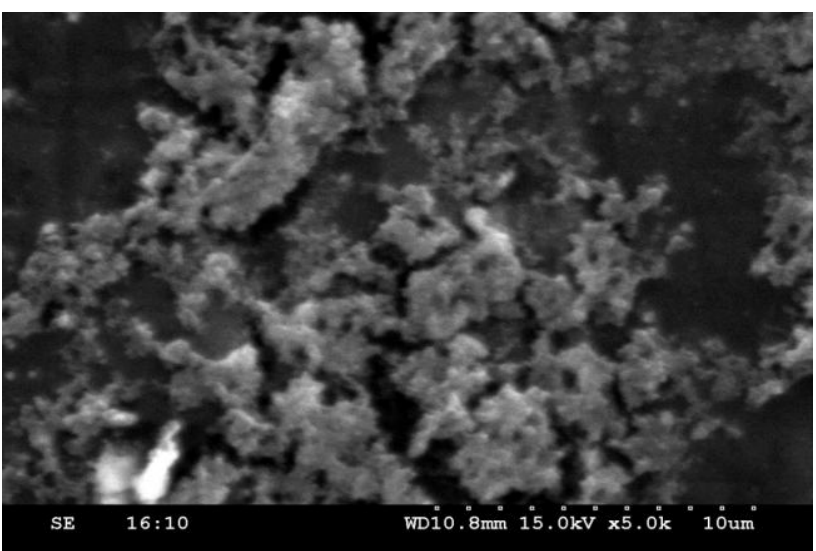

Fig. 7: SEM image of synthesized AgNPs of Sonneratia apetala leaf extract.

\section{Antibacterial activity of AgNPs}

The results on the antibacterial activity of AgNPs (Fig-8) clearly indicated the promising role of nanoparticles as antibacterial agents. Few photographs showing the clear zones formed by $S$. apetala leaf silver nanoparticles are presented in Plate-1. The silver nanoparticles displayed antibacterial activity against all the tested bacteria except Salmonella enterica. However, Proteus mirabilis and Arthrobacter protophormiae showed more susceptibility towards the AgNPs when compared to the streptomycin, with inhibition zones measuring $27.3 \mathrm{~mm}$ and $23.3 \mathrm{~mm}$, respectively. More antibacterial activity of AgNPsthan the streptomycin positive control was also observed against Micrococcus luteus, Bacillus subtilis, Pseudomonas aeruginosa and Alcaligensfaecalis. Surprisingly, Rhodococcus rhodochrous and Enterobacter aerogenes that were found totally resistant to streptomycin showed considerable susceptibility to silver nanoparticles.

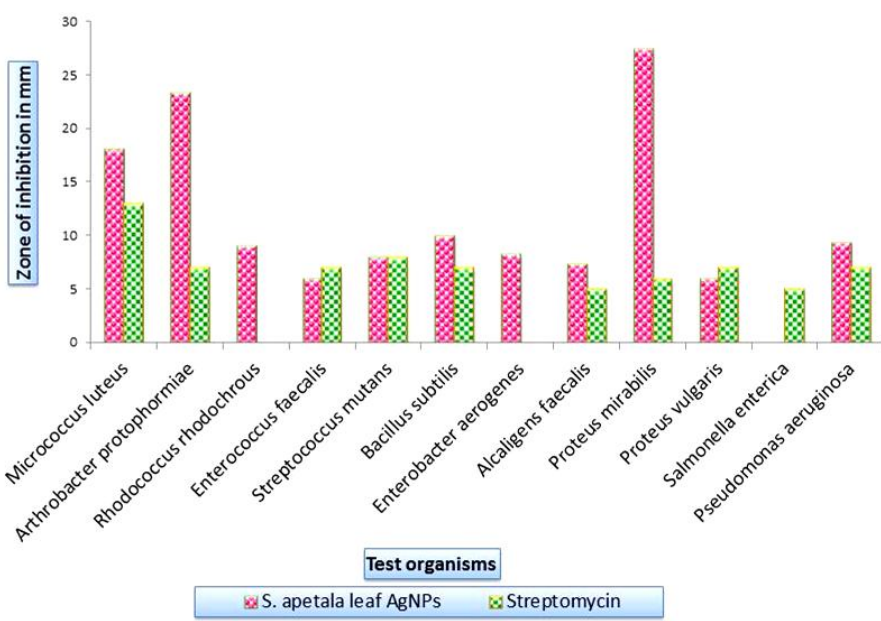

Fig. 8: Antibacterial activity of Sonneratia apetala leaf extract AgNPs against various bacteria.
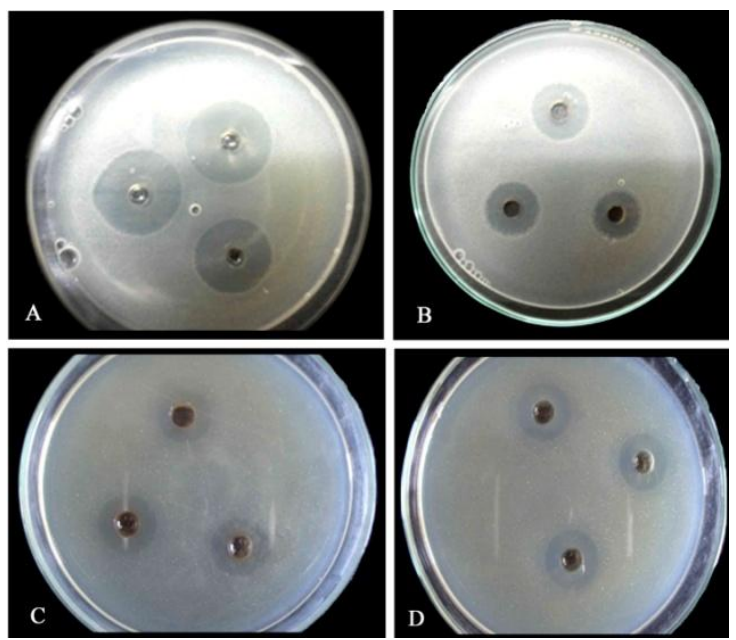

Plate-1. Antibacterial activity of Sonneratia apetala leaf extract AgNPs

A) AgNPs activity against Proteus mirabilis

B) AgNPs activity against Arthrobacter protophormiae

C) AgNPs activity against Bacillus subtilis

D) AgNPs activity against Micrococcus luteus

\section{DISCUSSION}

The current investigation revealed the presence of several phytochemicals, good antibacterial and antioxidant activity. These activities are may be due to the presence of different phytochemical classes. Moreover, these phytochemicals are 
responsible for the stabilization of AgNPs. Several earlier reports correlated the plant phytochemicals with their bioactive attributes and reported the antibacterial and free radical scavenging activities of the phytochemical constituents (Ali et al., 2002; Dahija et al., 2014; Medini et al., 2014; Mohammed et al., 2014; Lunga et al., 2014). The quantity of phytochemical components may vary with the plant part, leaf and stem (Patra et al., 2011). Saponins are liable for precipitation and coagulation of red blood cells, cholesterol binding, haemolytic activity, froth formation in aqueous solutions and bitterness. On the other hand, flavonoids are cogent water soluble antioxidants and free radical scavengers which can avert oxidative cell damage. Besides, they are also known to have strong anticancer activity. Steroidal components are of great prominence in pharmacological aspect for the reason that of their association with sex hormones (Okwu, 2004). Alkaloids are in use as primary medication agents for antispasmodic, analgesic and antibacterial effect (Okwu, 2001). Phenolic constituents generally observed in plants are stated to have potential antioxidant and antimicrobial activities. Different phenolic compounds such as tannins existing in plant cells are effective inhibitors of hydrolytic enzymes used by plant pathogens. A number of studies have been concentrated on the biological activities of phenolic compounds, which are acting as powerful antioxidants and free-radical scavengers (Devi et al., 2011). The healing properties of medicinal plants are well recognized at worldwide level, particularly for antibiotic development. Hence, the research of alternative and efficient medicines from plants against resistant bacteria has become an important concern all over the world (Wikaningtyas and Yulinah, 2016). PrabhuTeja and Ravishekar (2013) prepared the ethanol extracts of $S$. apetala plant parts viz., leaves, bark and pneumatophores and reported the incidence of alkaloids, flavonoids, tannins, saponins, phytosterols and carbohydrates. Ethanol extract of $S$. apetala fruit also found to contain alkaloids, reducing sugars, tannins, steroids, glycosides, flavonoids and acidic compounds (Anha et al., 2014). Patra et al (2015) have screened leaves and bark of $S$. apetala using acetone, ethanol, methanol and aqueous extracts and reported the alkaloids, cardiac glycosides, gums, anthraquinones, mucilages, tannins, steroids, flavonoids, carbohydrates, proteins and amino acids and terpenoids. The appearance of saponins, tannins, flavonoids, glycosides and terpenoids was also reported in the ethanol, methanol and aqueous extracts of Borassus flabellifer (Muthukumar et al., 2014). Several of the molecules fitting to various categories of secondary metabolites are noticed as active on pathogenic organisms (Awouafack et al., 2013; Cowan, 1999; Ndhlala et al., 2013; Tsopmo et al., 2013) and also the distinct mechanisms of action of their bioactive constituents. Phenols are the precise crucial plant components with diverse biological roles including antioxidant activity and their radical scavenging ability is reasoned to their OH groups (Vinayagam and Sudha, 2011). Several earlier reports stated that the mangrove plants are being used as traditional as well as modern systems of medicine, because mangroves contain bioactive compounds that may be of potential use in the long-term treatment of major disorders and diseases. In our present investigation, in addition to molecules already reported we found the presence of terpenoids. Hossain et al (2013) have reported that the antioxidant potential of fruit of $S$. apetala and Patra et al (2015) reported the antioxidant activity of $S$. apetala leaf and bark which confirms our findings. The absorption maxima of AgNPs in that range perhaps the end result of surface plasmon resonance of AgNPs (Priyabenarjee et al., 2014). The absorption peak at $1619 \mathrm{~cm}-1$ might be owing to the $\mathrm{C}=\mathrm{O}$ amide bond of a protein (Macdonald and Smith, 1996) and the absorption peak at $3417 \mathrm{~cm}-1$ could be of $\mathrm{OH}$ group existing in phenolics and alcohols (Ali et al., 2011; Jilie and Shaoning, 2007; Theivasanthi and Alagar, 2012). It is well known that the change in the shape of metal nanoparticle is a substantial change of their electronic and optical properties (Jana et al., 2000). The larger AgNPs might be formed by the aggregation of smaller ones that is owed to SEM measurements (Devaraj et al., 2013). The AgNPs own the capability to bind to the bacterial cell wall and eventually penetrate, and leads to modification cell membrane structure. As a result, the permeability of the plasma membrane changes that may cause the death of the cell. There is a chance for the occurrence of cavities and assembly of nanoparticles on the cell surface (Sondi and Salopek-Sondi, 2004). AgNPs forms free radicals which can be considered as another reason for the death of cells. Some Electron Spin Resonance Spectroscopy studies demonstrated that free radicals may be formed by the AgNPs when they are in contact with the bacteria, and these free radicals are able to disrupt the cell membrane and make it permeable which can finally lead to cell death (Danilcauk et al., 2006; Kim et al., 2007). These nanoparticles have been shown to accumulate inside the membrane and can subsequently penetrate into the cells causing damage to cell wall or cell membranes. It is of thought that silver atoms bind to thiol groups $(-\mathrm{SH})$ of enzymes forming stable ( $\mathrm{S}-\mathrm{Ag}$ ) bonds with thiol containing compounds and then it causes the deactivation of enzymes in the cell membrane that involve in trans membrane energy generation and ion transport. It was proposed that $\operatorname{Ag}(\mathrm{I})$ ion enters the cell and intercalates between the purine and pyrimidine base pairs disrupting the hydrogen bonding between the two anti-parallel strands and denaturing the DNA molecule. Bacterial cell lysis could be one of the reasons for antibacterial property of plant extract mediated silver nanoparticles (Ahmed et al., 2016).

It is also observed that nanoparticles are able to regulate the signal transduction in bacteria. It is a fact that the phosphorylation of protein substrates in bacteria determines bacterial signal transduction. Nanoparticles may alter the phosphotyrosine profile of bacterial peptides and dephosphorylation is realized in the tyrosine residues of Gram -ve bacteria. It was reported that the nanoparticles dephosphorylate the peptide substrates of tyrosine residues, leading to signal transduction inhibition and thus the termination of growth (Shrivastava et al., 2007). The variation in the level of antibacterial activity between Gram +ve and Gram -ve bacteria in this study may be the outcome of the arrangement pattern of cell 
wall components. AgNPs are especially known for their antibacterial properties. The widespread cases of multidrug resistant bacteria against the standard antibiotics have led researchers to potentially incorporate AgNPs and other nanomaterials as ingredient to boost the antibiotic effects (Ali et al., 2016). Morones et al (2005) reported the different facets of the AgNps and proposed three ways of bactericidal effect of AgNPs which include- disturbing the proper function of the bacterial cell, causing damage by interaction with phosphorus and sulfur containing groups in DNA molecule of the bacterial cells, release of silver ions from nanoparticles resulting in additional contribution to the bactericidal effect. $\mathrm{Ag}^{+}$mainly impacts the function of membrane bound enzymes, such as those in the respiratory chain (Mc Donnell and Russell, 1999). DNA loses its replication ability by treating bacteria with $\mathrm{Ag}^{+}$ions (Feng et al., 2000) and also inhibits expression of ribosomal subunit proteins as well as some other cellular proteins and enzymes essential to ATP production becomes inactivated (Yamanaka et al., 2005). By using these diversified bioactive chemical components with the AgNPs, there is a scope for the development of new medicine for the dreadful diseases.

\section{CONCLUSION}

The present investigation involved the screening and evaluation of $S$. apetala leaf crude extracts for the phytochemicals, antibacterial activity and antioxidant activity. Green synthesis of AgNPs using aqueous leaf extract, Characterization and antibacterial activity of synthesized nanoparticles were also carried out in the study. Outcome of all the experiments carried out suggests the existence of most of the phytochemicals in the leaves and are having some important biological activities. Further work is needed to isolate, purify and identify the exact active principle which is the cause for the biological activities. The Green synthesis is a simple, low cost and ecofriendly approach without any huge inputs in terms of energy. This is the first report of Green synthesis of silver nanoparticles for this plant. Being exhibiting greater antibacterial activity, phytochemical based nanoparticles may stand as a potential remedy in developing drugs against antibiotic resistant bacteria.

\section{ACKNOWLEDGEMENTS}

Authors are delighted to thank University Grants Commission, New Delhi for the financial support to accomplish this work.

\section{Financial support and sponsorship: Nil.}

Conflict of Interests: There are no conflicts of interest.

\section{REFERENCES}

Ahmed S, Ahmad M, Swami BL, Ikram S. A review on plants extract mediated synthesis of silver nanoparticles for antimicrobial applications: A green expertise. Journal of Advanced Research., 2016;7: $17-28$.
Ali DM, Sasikala M, Gunasekaran M,Thajuddin N. 2011. Biosynthesis and characterization of silver nanoparticles using marine cyanobacterium, Oscillatoria willei ntdm01. Digest J. Nanomater. Biostruct., 2011;6: 385-390.

Ali MS, Saleem M, Yamdagni R, Ali MA. Steroid and antibacterial steroidal glycosides from marine green alga Codium iyengarii Borgesen. Nat. Prod. Lett., 2002;16: 407-413.

Ali ZA, YahyaR, Sekaran SD,Puteh R. Green Synthesis of Silver Nanoparticles Using Apple Extract and Its Antibacterial Properties. Advances in Materials Science and Engineering., 2016: 1-6.

Anand SP, Doss A, Nandagopalan V. Antibacterial studies of Clitoriaternatea Linn. - A high potential medicinal plant. International Journal of Applied Biology and Pharmaceutical Technology., 2011; 2, 453 -456 .

Anha AS, Farzana SB, Sharmin I, Samir Kumar S.Phytochemical and Pharmacological Evaluation of Fruits of Sonneratia apetala. Pharma, Drug Discovery, Toxicology and Medicine., 2014; 14, 1 6.

Awouafack MD, Tane P, Kuete V, Eloff JN. 2013. Sesquiterpenes from the medicinal plants of Africa. In: Kuete, V. Eds. Medicinal Plant Research in Africa: Pharmacology and Chemistry. Elsevier: Oxford., p.33-103.

Chew AL, Jessica JJ, Sasidharan S. 2012. Antioxidant and antibacterial activity of different parts of Leucas aspera. Asian Pacific Journal of Tropical Biomedicine., 2012; 2: 176- 180.

Cowan MM. Plant products as antimicrobial agents. Clin.Microbiol. Rev., 1999; 12: 564-582.

Dahija S, Cakar J, Vidic D, Maksimovic M, Paric A. Total phenolic and flavonoid contents, antioxidant and antimicrobial activities of Alnus glutinosa (L.) Gaertn., Alnus incana (L.) Moench and Alnus viridis (Chaix) DC.Extracts. Nat. Prod. Res., 2014; 28: 2317-2320.

Danilcauk M, Lund A, Saldo J, Yamada H, Michalik J. Conduction electron spin resonance of small silver particles. Spectrochimaca. Acta. Part A.,2006; 63: 189-191.

Devaraj P, Kumari P, Aarti C, Arun R. Synthesis and Characterization of Silver Nanoparticles Using Cannonball Leaves and Their Cytotoxic Activity against MCF-7 Cell Line. Journal of Nanotechnology.,2013; 1, 1-5.

Devi GK, Manivannan K, ThirumaranG, Rajathi FA, Anantharaman P. 2011. In vitro antioxidant activities of selected seaweeds from southeast coast of India. Asian Pac J Trop Med., 2011; 4: 205-211.

Feng QL, Wu J, Chen GQ, Cui FZ, Kim TM, Kim JO. A mechanistic study of the antibacterial effect of silver ions on Escherichia coli and Staphylococcus aureus. J. Biomed. Mater. Res., 2000; 52: 662668 .

Harborne, J.B. 1973. Phytochemical methods. Chapmann and Hall Ltd: London; 1973. p.49- 188.

Harishchandra MR, Rajan PR, Singh Satyendrakumar RP. 2012. Study of krimighna effect of nimba (Azadiracta indica A.Juss.) Patra as rakshoghnadhoopan by culture and sensitivity method W.S.R. to pyogenic bacteria. International Research Journal of Pharmacy 2012; 3: 142- 146.

Hossain SJ, Basar MH, Rokeya B, Arif KMT, Sultana MS, Rahman MH. Evaluation of antioxidant, antidiabetic and antibacterial activities of the fruit of Sonneratia apetala (Buch.-Ham.). Orient Pharm Exp Med., 2013; 13: 95-102.

Jana NR, Wang ZL, Sau TK, Pal T. Seed-mediated growth method to prepare cubic copper Nanoparticle, Current Science., 2000; 79: 1367-1369.

Jilie K, Shaoning YU. Fourier transform infrared spectroscopic analysis of protein secondary structures. Acta Biochim Biophys Sin. 2007; 39: 549-559.

Kim JS, Kuk E, Yu K, Kim JH, Park SJ, Lee HJ, Kim SH, Park YK, Park YH, Hwang CY, Kim YK, Lee YS, Jeong DH, Cho MH. Antimicrobial effects of silver nanoparticles. Nanomedicine., 2007; 3: 95101.

Lunga PK, Qin XJ, Yan XW, KuiateJR, Du ZZ, Gatsing D. 2014. Antimicrobial steroidal saponin and oleanane-type triterpenoidsaponins from Paullinia pinnata. BMC Complement Altern. Med., 2014; 2: 1-7. 
Macdonald IDG, Smith WE. Orientation of cytochrome C adsorbed on a citrate-reduced silver colloid surface. Langmuir., 1996; 12: 706-713.

Mardani M, AfraSM, Tanideh N, AndishehTadbirA, Modarresi F, Koohi-Hosseinabadi O, Iraji A, SepehrimaneshM. Hydroalcoholic extract of Carum carvi L. in oral mucositis: a clinical trial in male golden hamsters. Oral Dis.,2016; 22: 39- 45.

Mc Donnell G, Russell AD. Antiseptics and disinfectants: activity, action, and resistance. Clin.Microbiol. Rev., 1999; 12: 147-179.

Medini F, Fellah H, Ksouri R, Abdelly C. Total phenolic, flavonoid and tannin contents and antioxidant and antimicrobial activities of organic extracts of shoots of the plant Limonium delicatulum. J. Taibah. Univ. Med. Sci., 2014; 8: 216- 224.

Mohammed RS, AbouZeid AH, ElHawary SS, Sleem AA, Ashour WA. Flavonoid constituents, cytotoxic and antioxidant activities of Gleditsia triacanthos L. leaves. Saudi J. Biol. Sci., 2014; 21: $547-553$

Morones JR, Elechiguerra JL, Camacho A, Holt K, Kouri JB, Ram'irez JT,Yacaman MJ.The bactericidal effect of silver nanoparticles. Nanotechnology., 2005; 16: 2346-2353.

Muthukumar A, Jothi D, Manohar M, Rajasingh Saranya R, Peraman M, Nachimuthu S. In vitro studies on phytochemical evaluation and antimicrobial activity of Borassus flabellifer Linn. against some human pathogens. Asian Pac J Trop Med., 2014; 7(S1): S182-S185

Nagababu P, Umamaheswara Rao V. Antibacterial activity and phytochemical screening of leaves and stem extracts of Avicennia alba Blume. International journal of applied biology and Pharmaceutical technology., 2012; 3: 399-405.

Nagababu P, Umamaheswara Rao V. Costeffective green synthesis and characterization silver nanoparticles from Avicennia alba Blume leaves and their antibacterial activity. Asian J Pharm Clin Res., 2016; 9: 301-303.

Ndhlala AR, Amoo SO, Ncube B, Moyo M, Nair JJ, Van Staden J. 2013. Antibacterial, antifungal, and antiviral activities of African medicinal plants. In: Kuete, V. Eds. Medicinal Plant Research in Africa: Pharmacology and Chemistry. Elsevier: Oxford., p. 621-659.

Nebula M, Harisankar HS, Chandramohanakumar N. Metabolites and bioactivities of Rhizophoraceae mangroves. Natural products and bioprospecting.,2013; 3: 207-232.

Okwu DE. Evaluation of the chemical composition of indigenous spices and flavouring agents. Global J Pure Appl Sci., 2001; 7 : 455-459.

Okwu DE. Phytochemicals and vitamin content of indigenous spices of south Eastern Nigeria. J Sustain Agric Environ., 2004; 6: 30- 37.

Patra JK, Das SK, Thatoi H. Phytochemical Profiling and Bioactivity of A Mangrove Plant, Sonneratia apetala, from Odisha Coast of India. Chin J Integr Med., 2015; 21: 274-285.

Patra JK, Dhal NK, Thatoi HN. In vitro bioactivity and phytochemical screening of Suaeda maritima (Dumort): A mangrove associate from Bhitarkanika, India. Asian Pacific Journal of Tropical Medicine., 2011; 4: 727-734.
PrabhuTeja V, RavishankarK. Preliminary phytochemical investigation and In vitro antimicrobial activity of ethanolic extract of Sonneratia apetala plant. International research journal of pharmacy., 2013; 4: 84-87.

Priya Banerjee, MantoshSatapathy, Aniruddha Mukhopahayay, Papita Das. Leaf extract mediated green synthesis of silver nanoparticles from widely available Indian plants: synthesis, characterization, antimicrobial property and toxicity analysis. Bioresources and Bioprocessing., 2014; 1: 1-10.

Sachin R, Shahana K, Rupali G. Isolation and characterization of major phytoconstituents from the leaves of Rhizophora mucronata Lamk and Acanthus ilicifolius Linn.Int. Res. J. of Sci. \& Engg., 2014; 2: 51- 59 .

Shrivastava S, Bera T, Roy A, Singh G, Ramachandrarao P, Dash D. Characterisation of nhanced antibacterial effects of novel silver nanoparticles. Nanotechnology., 2007; 18: 1-9.

Sivakumar J, Premkumar C, Santhanam P, Saraswathi N. Biosynthesis of Silver Nanoparticles Using Calotropis gigantean Leaf. African Journal of Basic \& Applied Sciences., 2011; 3: 265-270.

Sondi I, Salopek-Sondi B. Silver nanoparticles as antimicrobial agent: a case study on E. coli as a model for Gram-negative bacteria. Journal of Colloid and Interface Science., 2004; 275: 172-182.

Theivasanthi T, Alagar M. Electrolytic synthesis and characterizations of silver nanopowder. Nano Biomed. Eng., 2012; 4: 5865 .

Tsopmo A, Awah FM, Kuete V. 2013. Lignans and stilbenes from African medicinal plants. In: Kuete, V. Eds. Medicinal Plant Research in Africa. Elsevier: Oxford., p. 435-478.

Umamaheswara Rao V, Nagababu P. Phytochemical Screening, Antibacterial, Antioxidant and Anthelmintic Activities of Suaeda nudiflora (Willd.)Moq. Int. J. Pharm. Sci. Rev. Res., 2014; 29: 320-327.

Vinayagam A, Sudha PN. 2011. Antioxidant activity of methanolic extracts of leaves and flowersof Nerium indicum. International journal of pharmaceutical sciences and research., 2011; 2: 548-1553.

Wikaningtyas P, Yulinah Sukandar E. The antibacterial activity of selected plants towards resistant bacteria isolated from clinical specimens. Asian Pac J Trop Biomed., 2016; 6: 16-19.

Yamanaka M, Hara K, Kudo J. Bactericidal actions of a silver ion solution on Escherichia coli, studied by energy-filtering transmission electron microscopy and proteomic analysis. Appl. Environ. Microbiol., 2005; 71: 7589-7593.

\section{How to cite this article:}

Nagababu P, Rao VU. Pharmacological Assessment, Green synthesis and Characterization of Silver Nanoparticles of Sonneratia apetala Buch.-Ham. Leaves. J App Pharm Sci, 2017; 7 (08): $175-182$ 